The Catholic University of America, Columbus School of Law

CUA Law Scholarship Repository

\title{
Judicial Review in the Socialist Legal System: Current Developments
}

Rett R. Ludwikowski

The Catholic University of America, Columbus School of Law

Follow this and additional works at: https://scholarship.law.edu/scholar

Part of the Comparative and Foreign Law Commons

\section{Recommended Citation}

Rett R. Ludwikowski, Judicial Review in the Socialist Legal System: Current Developments, 37 INT'L \& COMP. L. Q. 89 (1988).

This Article is brought to you for free and open access by the Faculty Scholarship at CUA Law Scholarship Repository. It has been accepted for inclusion in Scholarly Articles and Other Contributions by an authorized administrator of CUA Law Scholarship Repository. For more information, please contact edinger@law.edu. 


\title{
JUDICIAL REVIEW IN THE SOCIALIST LEGAL SYSTEM: CURRENT DEVELOPMENTS
}

\author{
RHETT LUDWIKOWSKI*
}

DURING the past year the Western press has given publicity to new attempts to introduce judicial review into the socialist legal system. Some commentators recognise that challenging the communist government through legal routes is still a mere façade and that significant civil rights violations still continue in the Soviet bloc. ${ }^{1}$ Other commentators find the new institutions to be evidence of legal liberalisation widely heralded by reform-oriented Soviet leader, Mikhail Gorbachev.

When his personal collection of illegal underground literature was seized by police last year, Alexander P., a Warsaw journalist, decided to fight back. He sued for the return of his literature in the Supreme Administrative Court, Poland's increasingly active legal check on its communist-run bureaucracy. To his surprise and satisfaction, Alexander got his books back.

The spirit of his small triumph was recently shared by female university students, on whose behalf a case was lodged before the new Constitutional Tribunal. The suit challenged a decree by the Health Ministry limiting female enrolment to 50 per cent of the total enrolment at State medical schools. Despite government opposition, the quota was annulled. ${ }^{2}$

\section{TRADITIONAL CRITICISM OF JUDICIAL REVIEW IN SOCIALIST JURISPRUDENCE}

For Western experts on socialist legal systems, the current development of judicial control in the Soviet bloc seems to conflict with fundamental assumptions of socialist jurisprudence. Socialist law theorists traditionally argued that "the legislature is conceived to be the supreme expression of the will of the people and beyond the reach of judicial restraint". ${ }^{3}$ Legislation, not judicial decisions, was recognised as the

* Director and Professor of Law at the Columbus School of Law, Catholic University of America, Washington D.C.

1. Korygin, "Struggle Against the Inhumane", Washington Post, 19 May 1987.

2. Washington Post, 8 Mar. 1987.

3. J. N. Hazard, W. E. Butler and P. B. Maggs, The Soviet Legal System: The Law in the 1980s (1984), p.320. 
sole source of law in the socialist system. ${ }^{4}$ Marxist-Leninist jurisprudence rejects the doctrine of separation of powers, ${ }^{5}$ but allocates State functions to three governmental authorities (the legislature, executive and judiciary). It assumes that these segments of the socialist State work together under the leadership of the party. ${ }^{6}$ Thus, the segments of government were not separated and by no means equal. The supremacy of the legislative bodies was recognised as the fundamental premise of the socialist legal theory. As Lenin claimed, "the representation of the people is a nullity if it does not have full power". ${ }^{7}$

It was assumed that the legislative body was responsible for maintaining the constitutionality of State actions and that constitutional review could not be exercised by extra-parliamentary bodies. Constitutional control was usually reserved for internal organs of the legislative bodies which, like the Presidium of the Supreme Soviet of the USSR or the Council of State in Poland, exercise many of the powers of the parent body. ${ }^{8}$ Supervision over the observance of laws was vested in the procurator-general who was appointed by and responsible and accountable to the supreme legislative body. ${ }^{9}$

The constitutions of socialist countries are recognised as the supreme legal force, and it is assumed that all laws and other acts of State bodies will be promulgated on the basis of and in conformity with them. ${ }^{10}$ Without, however, the extra-parliamentary means of constitutional control, these provisions sound like political-philosophical declarations rather than legally binding norms. ${ }^{11}$ Traditional socialist legal theory assumes that an individual who believes that his constitutional rights have been violated could file a complaint in the executive branch supervising the office blamed for the violation or in the appropriate office of the procurator. Until recently the constitutions of socialist countries did

4. See V. M. Chkikvadze, The Soviet State and Law (1969), p.221; see also R. David and J. E. C. Brierly, Major Legal Systems in the World Today (1985), p.240; J. Hazard, I. Shapiro and P. B. Maggs, The Soviet Legal System (1969), p.40.

5. M. A. Glendon, M. W. Gordon and C. Osakwe, Comparative Legal Tradition (1985), pp.126-172; see also David and Brierly, op. cit. supra n.4, at pp.226-227.

6. "The Communist Party of the Soviet Union (CPSU) is a tried and tested militant vanguard of the Soviet people which unites, on a voluntary basis, the more advanced and the politically conscious section of the working class, collective-farm peasantry, and intelligentsia of the USSR." Rules of the Communist Party of the Soviet Union; see also USSR Constitution (1977), Art.6.

7. N. P. Farbierow (Ed.), Teoria Panstwa Socjalistycznego (1976), p.201.

8. USSR Constitution, Art.121, s.4; see also M. Cappelletti, Judicial Review in the Contemporary World (1971), p.7.

9. USSR Constitution, Arts.164, 165.

10. Idem, Art.173.

11. The "descriptive" rather than "prescriptive" role of the socialist constitutions was examined by M. Cappelletti and W. Cohen in Comparative Constitutional Law, Cases and Materials (1979), p.21; see also Cappelletti, "Repudiating Montesquieu? The Expansion and Legitimacy of Constitutional Justice" (1985) 35 Cath.U.L.Rev. 6. 
not serve as a basis for litigation and anyone could go to court to sue for violation of his rights. ${ }^{12}$ Socialist theorists traditionally claimed that in the socialist State the administration cannot be "set against" individuals. ${ }^{13}$ In accordance with Trotsky's logic, "the workers could not defend themselves against the workers". ${ }^{14}$ The institution of "bourgeois judicial review" was criticised as manipulative and instrumental in the hands of big capital. As Andrei Vyshinsky wrote:

Every sort of statute (in bourgeois countries) is considered as having force until it occurs to some private person or capitalist enterprise to file a petition to have it, or a separate paragraph of it, declared unconstitutional. Naturally this right is broadly used by monopolist cliques of exploiters to obtain a declaration of "unconstitutionality" as to laws running counter to their interests. ${ }^{15}$

Following Vyshinsky's argument, other socialist theorists also widely criticised the institution of judicial review. In Poland, Professor Stefan Rozmaryn wrote:

The constitutional control of statutes by extra-parliamentary bodies, particularly judicial and quasi-judicial, is a reactionary institution and because of that, there is no room for it either in a socialist State or in a State of people's democracy, which trusts the people's justice and the will of the people. ${ }^{16}$

\section{EARLY DEVELOPMENT OF JUDICIAL REVIEW IN EASTERN EUROPE}

WITH the denunciation by Khrushchev of the Stalinist dictatorship and criticism of the deviations of a bureaucratic centralism, socialist theorists raised the idea that adopting some modes of social control over the omnipotent administration might be crucial for the regeneration of socialist democracy. The representatives of the developing revisionism widely argued that the administration is never neutral and often tries to implement some political programmes which might depart from the interest of the represented class. They opted for reconstruction of judicial control of the administrative authorities which was abolished in the socialist countries of Eastern Europe after World War I.

Europeans who began to experiment with judicial control in the interwar period usually followed Austrian "centralised" type of control, con-

12. D. D. Barry and C. Barner-Barry, Contemporary Soviet Politics (1982), pp.82-83.

13. J. Lętowski, "Administracja i obywatele w PRL" (1984) 7 Panstwo i Prawo 52, 60.

14. S. Hendel, The Soviet Crucible. The Soviet System in Theory and Practice (1980), p.94.

15. A. Y. Vyshinsky, The Law of the Soviet State (1948), pp.339-340; the Soviet edition was published in 1938. 866.

16. S. Rozmaryn, "Kontrola Sprawiedliwosci Ustaw" (1946) 11-12 Panstwo i Prawo 
fining the power to review to a single judicial organ. ${ }^{17}$ In Austria this model was first tested in 1867 and adopted in the constitution of 1 October 1920 , as amended in $1929 .{ }^{18}$ The power to review the constitutionality of laws was vested in the Constitutional Tribunal, and to review the legality of administrative actions in the Supreme Administrative Court. Following the Austrian experience, judicial control of constitutionality was adopted by the Czechoslovakian constitution of 1920. Czechoslovakia also established the Administrative Tribunal in Bratislava. In 1921 the Supreme Administrative Tribunal was formed in Poland and, until the war, the Austrian model was adopted by most of the countries that had formally been under the influence of the AustroHungarian Empire. ${ }^{19}$

After the war, administrative tribunals were recognised as contrary to the basic principles of Leninism and as such ceased to operate in Bulgaria in 1944, in Romania in 1948, and in Hungary in $1949 .{ }^{20}$ Czechoslovakia's administrative tribunal did not "work" since the war, but was not officially closed until 1952. In Poland, which had been "liberated" by the Soviet army, it was simply not re-established. In the German Democratic Republic, the constitution of 1949 formally provided for the control of the legality of administrative actions but no administrative tribunals were established. ${ }^{21}$

In the late 1950s the attitude toward judicial control of administrative acts began to change in the socialist countries. The right of individuals to challenge the legality of administrative decisions was introduced by statutes in Yugoslavia in 1952, Hungary in 1957, Romania in 1967 and Bulgaria in 1970. These rights were later confirmed by constitutional amendments. ${ }^{22}$ Also, the 1977 constitution of the Soviet Union declared that "actions by officials that contravene the law or exceed their powers, and infringe the rights of citizens may be appealed in a court in the manner prescribed by law". ${ }^{23}$ In Czechoslovakia judicial review is theoretically provided for by the code of civil procedure, but there are no regulations which would implement the statute. Neither have there been

17. This model is usually contrasted with the American "decentralised" model which vests the power of control in all judicial organs; Cappelletti, op. cit. supra n.8, at p.46.

18. Z. Czeszejko-Sochacki, "Trybunal Konstytucyjny w. PRL" (The Constitutional Tribunal in the Polish People's Republic) (1986) Ksiazka i Wiedza 15-17.

19. M. Wiersbowski and S. C. McCaffrey, Modern Legal Systems Cyclopedia (1985), Vol.8, p.159.

20. Ibid.

21. Ibid.

22. A. Nowakowski, "Konstytucyjne podstawy dzialalnosci sadownictwa administracyjnego w Polsce" (Constitutional basis for the operation of administrative adjudication in Poland) (1985) 4 Panstwo i Prawo 70; see also M. Wyrzykowski, Sadowa Kontrola decyzji administracyjnych $w$ panstwie socialistycznym (Judicial Control of Administrative Decisions in the Socialist State) (1978), p.80.

23. USSR Constitution, Art.58. 
significant attempts to introduce judicial review in the German Democratic Republic. ${ }^{24}$

In the countries mentioned above, in which the control of the legality of administrative decisions was put into effect, individuals can seek judicial review of the questioned decision in the regular courts. This right may be exercised only after all administrative remedies have been exhausted; moreover, the review is limited exclusively to the legal basis of the administrative act. In Yugoslavia, the Administrative Disputes Act 1952 laid down that any final administrative act can be challenged in court and that the court's decision, after determination of any appeal, is binding. Until the promulgation of the 1974 constitution, administrative disputes were heard by the supreme courts of the republics and the Supreme Court of Yugoslavia. In accordance with the recent practice, the review of administrative decisions in the republics of Serbia and Vojevodina is in the jurisdiction of the regular district courts at first instance, and subsequently the supreme courts of the republics. In Bosnia and Hercegovina, disputes are heard by the special republic Administrative Court, in other republics the disputes are still handled by the supreme courts of the republics. ${ }^{25}$ Some countries, like Romania and Bulgaria, adopted judicial review in general but with several exceptions. For example, Romanian law 1/1967 provides a list of matters which cannot be submitted for judicial determination. They include matters of State defence and security, public order, central planning, epidemics and public calamities, tax and insurance; in addition, some other exceptions are provided for by special statute. ${ }^{26}$ In Bulgaria the exceptions from judicial review relate to matters of defence and security, social control, foreign currency exchange and decisions taken by the State apparatus. ${ }^{27}$ In contrast, Hungary's 1957 law enumerates areas in which judicial review is permissible. Five major spheres of judicial review were set forth, permitting it in the following areas:

(a) matters concerning refusal to include or to remove data from the registers of civil status;

(b) matters relating to assignments of apartments;

(c) matters on expropriation;

24. The development of judicial review in Poland as the most advanced of socialist legal systems will be discussed separately. Concerning the development of judicial review in East Germany, see Wyrzykowski, op. cit. supra n.22, at p.90; see also Wiersbowski and McCaffrey, op. cit. supra n.19, at p.161.

25. B. T. Blagojevic, "The Legal System of the Socialist Federal Republic of Yugoslavia", in Modern Legal Systems Cyclopedia, supra n.19, at pp.694-695.

26. T. Pop, "The Legal System of the Socialist Republic of Romania", in idem, pp.211-212.

27. Wiersbowski and McCaffrey, idem, pp.161-162. 
(d) matters concerning property taken into custody; and

(e) matters concerning taxation. ${ }^{28}$

In the Soviet Union the right to resort to regular courts is generally permissible under the 1977 constitution but is rarely exercised, and the list of areas in which the review is possible is not clearly specified.

In the early 1960 s socialist countries seemed also to consider introducing judicial control over constitutionality of legislation; however, with the exception of Yugoslavia, development in this direction was less impressive. Yugoslavia, which first started to experiment with the forms of judicial review, established the Federal Constitutional Court and the special constitutional courts in $1963 .{ }^{29}$ Czechoslovakia was also ready to introduce some forms of judicial control over the division of legislative competence between the federal government and federal units. However, Russian intervention in 1968 hampered the development of the system which was formally declared by the constitution of 27 October $1968 .^{30}$

Some other socialist countries, like Romania and Hungary, decided to adopt the principle of political rather than judicial control of constitutionality. This control is exercised either by the central legislative body or by the special organs composed of deputies and extra-parliamentary experts on constitutional law. Cappelletti states:

The recent Romanian Constitution of 1965, although not admitting to judicial control such as that adopted in 1963 Yugoslavia . . . has instituted within the Parliament itself a "Constitutional Committee", elected by Parliament. Up to maximum of a third of the total number of its members, the Committee may be composed of specialists who are not members of Parliament. The Committee under Article 53 of the Constitution has the task of putting before the "Great National Assembly" reports and opinions on the constitutionality of bills, on its own initiative or at the request of the bodies as indicated by the rules of Parliamentary procedure. $^{31}$

A similar organ was constituted in Hungary in 1984. The Council of the Constitutional Law is expected to co-operate with other State organs in protection of constitutionality and legality of all statutes, decrees and ordinances. Eleven to 17 members of the Council are selected by the

28. Experts on Hungarian law comment that after the adoption of the new statute in 1981 there is a tendency to increase the number of matters that may be appealed; idem, p.162.

29. Arts.241-251 of the Federal Constitution of Yuglosvia; see also Law on the Yugoslav Constitutional Court (Institut de Droit trans.); compare (1963) 7 and (1965) 14 Recueils des Lois de la RSF de Yugoslavie.

30. Cappelletti, op. cit. supra n.8, at p.51; see also David and Brierly, op. cit. supra n.2, at p.241.

31. Idem, pp. 10 and 241 respectively. 
National Assembly from deputies and "of the personalities of political life". 32

One must admit that, in socialist countries, the role of judicial review as an instrument for protection of constitutional rights of individuals is, so far, rather symbolic. However, practices established in the late 1950 s and 1960s undermined the general principle that judicial review was incompatible with the Marxist-Leninist doctrine and paved the way for the further-reaching development of this institution in Poland in the 1980s.

\section{CURRENT DEVELOPMENT OF JUDICIAL REVIEW OF ADMINISTRATIVE ACTIONS IN POLAND ${ }^{33}$}

THE tradition of Polish administrative adjudication dates back to the period when partitioned Poland was subject to the jurisdiction of Austrian and Prussian administrative courts. After World War I, with the restoration of independent Poland, the Polish constitution of 17 March 1921 announced the establishment of the Supreme Administrative Tribunal and the local administrative courts. The Tribunal was actually set up by statute on 3 August 1922, but the lower administrative courts were not established and the next constitution of 23 April 1935 provided for the Tribunal but did not mention anything about the administrative courts of first instance. ${ }^{34}$ After World War II, the Supreme Administrative Tribunal was left inoperable and some of its functions relating to the system of social insurance were taken over by the Tribunal of Social Security. The constitution of 22 July 1952, as amended in 1976, did not provide for administrative courts.

Some commentators have argued that the constitution of 1952 did not vest the regular courts with the right of control over the constitutionality of statutes and decrees. On the other hand, it laid down the principle that judges were bound only by statutes. Following this principle some Polish specialists on administrative law concluded that, a contrario, judges, who are bound by statutes, cannot decide against them. This meant that at least theoretically they should refuse to apply sub-statutory acts and administrative decisions which do not correspond with the statutes. ${ }^{35}$ Until 1980 neither the right of the judges to control the legality of sub-statutory acts nor the right of individuals to ask the regular courts to review the legality of administrative decisions was clearly provided for by any regulation. So, in accordance with the 1960 Code of

32. Czeszejko-Sochaki, op. cit. supra n.18, at p.19.

33. For a comparison of judicial control of administrative action in Poland and in the UK, see Reid, "The Approach to Administrative Law in Poland and in the United Kingdom" (1987) 36 I.C.L.Q. 000-Ed.

34. Nowakowski, op. cit. supra $\mathrm{n} .22$, at pp.65-67.

35. Czeszejko-Sochaki, op. cit. supra n.18, at pp.126-127. 
Administrative Procedure, the only permissible appeal against administrative decisions could be filed in the superior administrative agency. ${ }^{36}$

In the late 1960s the attitude toward the judicial review of administrative decisions began to change. As the result of a long dispute the two parliamentary committees prepared in 1977-79 a bill amending the Code of Administrative Procedure. On 31 January 1980 the bill was adopted by the Polish parliament (the Polish parliament is also referred to as the Seym). ${ }^{37}$

The new statute provided for establishment of the Supreme Administrative Court (Naczelny Sad Administracyjny, hereafter referred to as "N.S.A." or the Supreme Administrative Court) in Warsaw and in local districts which were to cover several provincial administrative units. ${ }^{38}$ The judges of the N.S.A. are appointed by the State Council (the collective organ of the parliament which exercises the powers usually attributed to the head of State) upon the recommendation of the Minister of Justice. From these judges, upon the recommendation of the prime minister, the State Council appoints the chief justice and deputy chief justice. ${ }^{39}$ The statute requires that judges be Polish citizens who are at least 35 years old; they must be graduates from law school and they must have had at least ten years' experience in any of the following professions: procurator, member of the State Arbitrazh, ${ }^{40}$ professional judge, advocate, notary, jurisconsult or senior legal officer in any of the administrative agencies. Professors of law schools are eligible without these experience requirements. Candidates must meet all standards of knowledge and character required of judges of regular courts. The judges of the N.S.A. are independent and bound only by statutes. ${ }^{41}$ They retain their position for life unless they are recalled, which they may be if they resign, reach 65 years of age, cannot perform their duties due to illness, or if their spouse is a practising attorney. ${ }^{42}$ The judges of the N.S.A. are subject to the same regulations as judges of the provincial courts but receive a salary equivalent to justices of the Supreme Court.

The N.S.A. is recognised as a special court which is subject only to the supervision of the Supreme Court. Decisions of the N.S.A. are final

36. L. Garlicki, "Polish Constitutional Development in 1980", in W. E. Butler (Ed.), Anglo-Polish Legal Essays (1982), p.156.

37. Idem, p.157.

38. Statute on the Supreme Administrative Court and amendment to the statute, Code of Administrative Procedure, of 31 Jan. 1980, Art.1. Local sections of N.S.A. have been established in Gdansk, Katowice, Krakow, Lublin, Poznan and Wroclaw.

39. Statute of 31 Jan. 1980 (hereafter cited as the "Statute").

40. In socialist States, State Arbitrazh, sometimes called Economic Courts, usually handle the disputes arising out of contracts among State enterprises, co-operatives, social enterprises as well as other economic agencies.

41. Statute, Art.4.

42. See Wiersbowski and McCaffrey, op. cit. supra n.19, at p.164. 
and can be challenged in the Supreme Court only by way of supervisory review, which is a type of extraordinary appeal within the discretion of the Chief Justice of the Supreme Court, Procurator-General and Minister of Justice. ${ }^{43}$

The right to seek judicial review of an administrative decision is vested in the party whose interest was affected by the challenged action, the social organisation which participated in the challenged proceeding, or the procurator. ${ }^{44}$ The petition can be filed in the Supreme Administrative Court after exhaustion of administrative remedies but not later than 30 days after the issue of the final administrative decision. For the procurator, this term is extended up to six months. A petition is filed through the administrative agency which issued the challenged decision. The rationale for this provision was to give the administrative organ a chance to review its position before it would be formally appealed in court. This right can be exercised by the agency up to 30 days after the petition was submitted to the administrative agency. The petition does not automatically suspend the administrative agency action, but a decision concerning suspension might be taken up by the administrative agency or the Court.

The Supreme Administrative Court is not limited by the charges invoked in the petition but is limited to issues of law. ${ }^{45}$ The Court will set aside the decision if it finds substantial or procedural non-compliance with the laws. If the Court finds that the decision was clearly contrary to the law, it will declare the earlier decision invalid. As Wiersbowski commented, "The degree of hardship caused by the errors committed by the administrative authority determines whether a decision should be set aside or declared invalid." 46 The Court may also reject the petition if it does not meet the formal procedural requirements, or may dismiss the petition on the basis of the review allowing the administrative agency's decision to stand. ${ }^{47}$

The Code of Administrative Procedure, as amended in 1980, provides a long list of 20 areas of administrative law in which the parties can petition for review by the N.S.A. The list includes decisions dealing with architecture and building operations; prices, tariffs and dues; public roads, traffic, communication, sailing and transport; trade, craft and the catering business census and data from registers of civil status; geology, land surveying and map-drawing; housing management; power engineering management; water and food supplies management; taxes and customs duties except those paid by State units; real estate and personal

43. Statute, Art.5.

44. Code of Administrative Procedure, as amended in 1980, Art.197.

45. Idem, Art.206; see also Garlicki, op. cit. supra n.36, at p.160.

46. See Wiersbowski and McCaffrey, op. cit. supra n.19, at p.166.

47. Code of Administrative Procedure, Art.207, ss.5 and 6. 
property; environmental protection; art protection, culture and education; town and country planning, agriculture and forestry; licences; expropriations; employment; public health, social security, sport, tourism, and sanitary requirements. American mass media announced that it is likely that the Court will be allowed to hear cases dealing with refusals of passports to opposition activists and requests by new organisations for government recognition. ${ }^{48}$ So far, however, Polish experts comment that these spheres, as well as decisions expelling foreigners from Poland and relating to military conscription, remain immune from judicial review. ${ }^{49}$

Overall reaction to the Court's activities is favourable. As the Washington Post concluded from a series of interviews in Warsaw, "About 13,000 cases were heard last year [1986] and according to a calculation by Podemski ${ }^{50}$ the citizens' suits succeeded more than a third of the time. ${ }^{51}$ In 1981 the government, under strong public pressure, allowed an appeal to the N.S.A. against decisions on censorship of the press and publications which violated the Statute on the Control of Press and Publications. ${ }^{52}$ In 1982, the Statute on Universities permitted universities to appeal to the Court against some decisions of the Minister of Science, Technics and Education. ${ }^{53}$ As Wiersbowski commented, "these two examples demonstrate popular support for the idea of judicial review by the N.S.A. of administrative decisions". ${ }^{54}$ There is no doubt that the N.S.A. is an important factor in Poland's administrative law. Compared to other socialist countries, which permit appeals to their regular courts in relatively few areas of administrative decisions, the Polish reform has to be assessed as an important step toward democratisation of the mechanisms of social control in the area of administrative legality. The justices of the Court are better prepared to hear administrative disputes than the judges of the regular courts. So far, their independence does not seem to be challenged by governmental pressure, especially since Jaruzelski's government wants to improve its public credibility and build a "liberal" image in the West. There is no doubt that the judges of the Court are carefully selected to fulfil this function and that, until recently, the Court's role corresponded both with the general atmosphere of Gorbachev's "glasnost" and with the intentions of Jaruzelski's government to curb the abuses of the local bureaucrats. On the other hand, some experts argue that without active support of the policy-

48. Washington Post, supra n.2.

49. Wiersbowski and McCaffrey, op. cit. supra n.19, at p.165.

50. Stanislaw Podemski is a Polish lawyer and journalist who was interviewed by the Washington Post.

51. Washington Post, supra n.2.

52. Dziennik Ustaw (Official Registry of the Current Legislature), 20/1981.

53. Dziennik Ustaw, 14/1982.

54. Wiersbowski and McCaffrey, op. cit. supra n.19, at p.167. 
making structures the role of the court might be easily reduced to that of a rubber stamp. Even recently, reports indicate that governmental departments are attempting to boycott or simply disregard the Court's decisions. ${ }^{55}$

Looking at this phenomenon from a societal perspective, it would be beneficial if the Court were allowed gradually to build its social credibility and independence without seriously challenging the communist administrative policy. The very fact of the establishment of an institution of judicial review over administrative actions in a special court is precedential and, despite the fact that so far there are no indications that other Eastern European countries are eager to adopt the Polish model, in the future the Polish experiment may strongly affect the development of administrative law within the Soviet bloc. ${ }^{56}$

\section{JUDICIAL REVIEW OF THE CONSTITUTIONAIJITY OF LEGISLATION IN POLAND}

\section{A. The Establishment of the Constitutional Tribunal}

In the early 1960s in Poland the attitude toward the judicial control of the constitutionality of legislation also began to change. As soon as 1961 some Polish experts on constitutional law cautiously began to drop hints that judicial review might be a useful institution in socialist countries. This opinion was clearly expressed during the Conference of the Institutes of Constitutional Law in Kazimierz in $1961,{ }^{57}$ and was supported by two influential law professors, Andrzej Burda and Feliks Siemienski. ${ }^{58}$ The idea of establishing a Constitutional Tribunal was supported by the Democratic Party (one of the political groups cooperating with the leading Polish United Workers' Party) and by the "advocatura" (the aggregate of all existing colleges of advocates) ${ }^{59}$ The problem was also discussed at the Ninth Congress of the Polish United Workers' Party in July 1981 and, as a result of the generally positive atmosphere, the Polish Seym Deputies Club decided to appoint a com-

55. S. Podemski, "Straznik Naszych Praw" (The Guardian of Our Rights) (1986) Polityka (Politics) No.42, 18 Oct.

56. Wiersbowski and McCaffrey, op. cit. supra $\mathrm{n} .19$, at p.169.

57. Report on the conference which was published in (1961) 12 Panstwo i Prawo; see also Czeszejko-Sochaki, op. cit. supra n.18, at p.29.

58. Czeszejko-Sochaki, idem, p.30; see A. Burda's review of the work of Janina Zakrzewska in "Kontrola Konstytucyjnosci ustaw" (1965) 5-6 Panstwo i Prawo 67; F. Siemienski, "Poblem Konstytucyjnosci ustaw w Panstwie Socjalistycznym" (The Problem of Constitutionality of the Laws in a Socialist State) RPEIS, 1972/4 $10 \mathrm{et} \mathrm{seq.}$

59. Beginning in 1946 the Polish Democratic Party began to examine the possibility of establishing a Constitutional Tribunal. Finally the Party's Congress in March 1981 supported this project; see Czeszejko-Sochaki, op. cit. supra n.18, at p.45; see also the report from the Congress of Advocatura in Poznan, Jan. 1981. 
mittee of experts to prepare the project. ${ }^{60}$ In February 1982 the constitutional amendment introducing the Constitutional Tribunal and the Tribunal of State was submitted to the Polish Seym. ${ }^{61}$ The appropriate constitutional amendment, Article 33a, was adopted on 26 March 1982, and after three years of work the final statute on the Constitutional Tribunal was published on 29 April $1985 .{ }^{62}$ The Tribunal began to review cases from 1 January 1986.

\section{B. Organisation and Composition of the Tribunal}

The Constitutional Tribunal is located in Warsaw. The Tribunal is composed of a chief justice, a deputy chief justice and ten justices. All justices are elected by the Seym to sit on the bench for eight years. Re-election is not permitted, except in the situation where a justice is selected to fill a vacant position for a period shorter than four years. The relevant statute provides that candidates must be highly qualified in law and must possess the numerous qualifications required of Supreme Court justices. In accordance with the Statute of 20 September 1984, a justice of the Supreme Court should be a Polish citizen who enjoys full rights of citizenship and whose conduct and personality guarantee that he will correctly fulfil his duties. He or she should be a law school graduate and possess regular judicial qualifications (judicial apprenticeship) and have at least ten years' experience in any of the following professions: procurator, professional judge, member of the State Arbitrazh, advocate, jurisconsult or as a senior legal officer in an administrative agency. Professors of law are exempted from the experience requirement. A justice cannot combine his position on the Constitutional Tribunal with a seat in the Seym or with any other State position. The statute states that a justice cannot perform any function which could conflict with his duties as a member of the Tribunal. However, some Polish commentators argue that a justice may keep his position as a professor in a law school. ${ }^{63}$

60. The committee of experts had seven members: Professors Andrzej Burda, Henryk Groszczyk and Jan Ziembinski, all from Lublin University, Professors Arnold Gubinski, Andrzej Gwizdz, Jerzy Jodlowski, all from Warsaw University, and Professor Leszek Kubicki who was from the Polish Academy of Sciences.

61. The Tribunal of State, which is not discussed in this article, adjudicates on matters that focus on liability of high State officials. See Statute on the Tribunal of State, in Dziennik Ustaw 11/1982, statute of 26 Mar. 1982; see also J. Wroblewski, "Trybunal Stanu i Trybunal Konstytucjny-zwiazki instytucjonaine i problemy ws polne" (Tribunal of State and Constitutional Tribunal . .. Institutional connections and common problems) (1986) 8 Panstwo i Prawo.

62. The detailed procedure for the Tribunal was provided for by law on 31 July 1985 . See Dziennik Ustaw, Art.22, s.98, 1985 (Pol.) and Dziennik Ustaw, Art.39, s.184, 1985 (Pol.).

63. Czeszejko-Sochaki, op. cit. supra n.18, at p.73. 
A justice can be recalled by the Seym if he resigns, is permanently ill and unable to perform his duties, if he is sentenced by the criminal court or is impeached by the Tribunal, or if he is found disloyal to the vows he is pledged to uphold. ${ }^{64}$ The statute ensures that the justices are independent and bound only by the constitution; it does not provide for supervisory review of the Tribunal's decisions by the Supreme Court. The Tribunal, unlike the Supreme Administrative Court, is answerable only to the Seym which is the supreme organ of State power.

\section{The Scope of the Constitutional Review}

The various constitutions of socialist countries emphasise the unity and the hierarchical structure of the socialist juridical system. Under this structure, the constitution is located at the top of the legislative pyramid. Statutes, as the laws adopted by the highest organs of State power (Soviets, Parliaments, Seym) are recognised as the principal and dominant source of socialist law regulating matters of primary importance. All other law-making acts are issued on the basis of and pursuant to statutes. ${ }^{65}$ These other law-making acts include:

(a) decrees, which are issued by the standing organs of the highest legislative bodies (State Councils or Presidiums of the Supreme Soviets), and are submitted to the parliament for approval during its next session;

(b) orders and ordinances which are issued by the Council of Ministers; and

(c) orders and instructions which are issued by ministers and heads of other central departments. ${ }^{66}$

All these acts are subject to constitutional review by the Constitutional Tribunal, but the final decisions of the Tribunal are limited to sub-statutory acts (orders, ordinances and instructions). The president of the Tribunal submits a decision declaring unconstitutional a sub-

64. Art.13, ss. 2 and 5 of the statute of 29 Apr. 1985 (hereinafter referred to as "1985 Statute").

65. Professor W. Zakrzewski, as a chairman of the Legislative Committee of the Polish Seym, presented the project to create a Constitutional Tribunal. He defined the "lawmaking act" as "an act that lays down the rules and patterns of conduct which are compulsory for the addressee of the act regardless of the legal basis of the act, objective and subjective scope and the form of the sanction provided for the observance of the act." Zakrzewski, Zakres przedmiotowy i formy dzialalnosci prawotworczej (Objective Scope and Form of Law-making Activity) (1979), p.85; see also Czeszejko-Sochaki, op. cit. supra $\mathrm{n} .18$, at p. 85 .

66. Local organs of authority and their executive administrative organs issue "decisions" which, as discussed above in Poland, can be appealed to the Supreme Administrative Court, and in most of the other socialist countries, can be appealed to regular courts. 
statutory normative act to the organ which issued the act. If the organ does not amend the act in $\mathbf{3 0}$ days as directed by the Tribunal, the act becomes invalid. After issuing its decision, the Tribunal may, under special circumstances, suspend the act. Once the Tribunal has ruled and declared the statutory acts (either statutes or decrees) unconstitutional, it should submit its decision to the Seym for further approval. The Seym can then overrule the Tribunal's decision by a qualified two-thirds majority of at least half the deputies voting. ${ }^{67}$

Contrary to the opinions of certain groups concerning the bill on the Constitutional Tribunal (a "project" which was presented to the Seym on 1 March 1982), the final statute of 1985 placed the review of international agreements outside the Tribunal's sphere of power. During the parliamentary disputes prevailing opinion stressed that "the legal status of an international agreement is not regulated by constitutional law", 68 and that the Tribunal is limited to controlling acts which are "adopted" not "contracted". 69

Article 2 of the statute limits the Tribunal's power of review to the following areas: the substance of the challenged act, the capacity of the organ which issued the act and/or the procedure which was followed by the organ. In the opinion of Polish experts, each of these factors sufficiently justifies challenging an act. ${ }^{70}$

Article 3 of the statute provides that the acts of statutory rank are subject to constitutional review from the moment of their publication in the Official Register of Statutes (Dziennik Ustaw). Decrees can be reviewed once they have been approved by the Seym, and sub-statutory acts can be reviewed from the moment of their adoption by the appropriate organ. Review of such acts must be instituted within five years from the date of publication, approval or adoption of the appropriate act. ${ }^{71}$

Generally speaking, countries which try to develop a system of judicial review usually adopt one of two major models: the centralised, so-called Austrian model, or the decentralised or so-called "American" model. The centralised/Austrian system of review, which reserves the right to review to one special judicial organ, was adopted by the constitutions of Italy in 1948, West Germany in 1949, Cyprus in 1960 and Turkey in 1961. The constitution of Yugoslavia, adopted in 1963, also

67. 1985 Statute, Art.6; see also Arts.1, 7, 8 and 9.

68. This is the opinion of Deputy A. Klafkowski, as quoted by Czeszejko-Sochaki, op. cit. supra n.18, at p.55.

69. This is the opinion of Deputy W. Zakrzewski, in the report from a meeting of the Seym on 29 Apr. 1985; idem, p.57.

70. M. Starzewski, Srodki Zabepieczenia Prawnego Konstytucyjonosci Ustaw (Ways of Legal Protection for the Constitutionality of Statutes) (1978), p.39.

71. 1985 Statute, Art.21. Polish constitutional law specialists claim that the term of five years refers only to the so-called "abstract" control. The distinction between "abstract" and "concrete" control is discussed below. 
provides for a special Federal Constitutional Court, but the review at the republic level is instituted by six republican constitutional courts. ${ }^{72}$ The decentralised American model, providing for the judicial control of all judicial organs, was adopted in many of the former British colonies (Canada, Australia, India), and was introduced in Japan. A "mixed" system was adopted by some European countries (e.g. Switzerland) which not only vests judicial review in the special tribunal, but also allows the regular courts to disregard laws in conflict with the constitution. ${ }^{73}$

Constitutional experts also distinguish between two ways of initiating judicial review: abstract review or concrete review. Abstract review (or review "principaliter") is initiated before the special court by special State organs or officials in special proceedings in which the constitutionality of the normative act is the principal matter being reviewed, independently of any pending case. In its classical version this system was adopted by the Austrian constitution of $1920 .{ }^{74}$ Concrete review (or "incidenter" review) may be initiated only in connection with a case pending in regular courts. The "concrete" system originated in America and was followed by the legal systems of Australia; Canada, Japan, Norway, Denmark and Sweden. The constitutional question cannot be reviewed by the court "as a separate issue" not connected with a pending case. The constitutional question is heard as a problem "incidental" to the dispute being heard by the court. ${ }^{75}$ Some countries, like Italy and Germany, adopted a mixed system which provides for one specialised court which hears constitutional cases, but the proceedings may be initiated either in the regular courts or in the special political organs through a direct action. The Polish Statute on the Constitutional Tribunal adopted a centralised and mixed system of judicial review.

The Polish Constitutional Tribunal is the single judicial organ vested with the power to review and to determine the constitutionality of normative acts. Constitutional proceedings can be initiated either through petition (an "abstract" review) or through inquiry by a regular court ("concrete" review).

\section{Access to the Constitutional Tribunal}

The right to file a petition is vested in the Presidium of the Seym, the Seym committees or groups of at least 50 deputies, the State Council or its chairman, the Tribunal of State, the president of the Supreme Committee of Control, the Council of Ministers or the prime minister, the

72. See Cappelletti, op. cit. supra n.8, at pp.50-51.

73. Idem, pp.48-49.

74. Idem, pp.71-77.

75. Idem, pp.69-71. 
presidents of the Supreme Court, Supreme Administrative Court and Arbitrazh, the Procurator-General, and the Executive Committee of the Council of the Patriotic National Movement of National Restoration. ${ }^{76}$ The specified petitioners can file a petition either on their own initiative or as a result of complaints or requests from the people. However, the right to file a petition on matters concerning security and defence is vested only in the Presidium of the Seym, the State Council, the Council of Ministers and the Committee of National Defence. The Constitutional Tribunal can review any case on its own initiative except for cases concerning defence and security.

An action by the organs and officials enumerated above initiates direct Tribunal review. The statute also vests the right to file a petition in a second group of petitioners, including local organs having authority at voivodeship (district) level and their executive administrative organs, trade unions, co-operatives, unions of socialist youth and professional organisations. This group may file petitions only in matters within the scope of their activity and the petitions are controlled initially by the Tribunal, which may leave a petition "non-pending". The Tribunal's decision on the propriety of the petition is made by a single judge; the complaint will eventually be heard by three judges, whose decision is final. ${ }^{77}$

Review by the Constitutional Tribunal may also be initiated by addressing an inquiry to the Tribunal. The constitutional issues raised in the inquiry have to be in connection with regular judicial proceedings. Moreover, the decision in the case will not be affected by the decision on the constitutional issue. The scope of the inquiry is broader than the petition. As Polish commentators claim, the courts are not limited by the security or defence-related character of the question. ${ }^{78}$ The statute provides that the proceedings in connection with which the inquiry is instituted are suspended from the moment of filing the inquiry in the Constitutional Tribunal and until the question of constitutionality is decided.

The inquiry initiated in a regular court in connection with judicial proceedings resembles the concrete (or incidenter) form of review. However, the regular courts do not have the right to apply directly to the Constitutional Tribunal for review. They can only notify their constitutional reservations to those organs or officials having the right to file an inquiry: the president of the Supreme Court, the president of Supreme Administrative Court, the president of the State Arbitrazh,

76. 1985 Statute, Art.19.

77. Idem, Art.20; see also L. Garlicki, "Trybunal Konstytucyjny a Rola Sadow w' Obronie Konstytucyjnosci Prawa" (Constitutional Tribunal and its Role in the Protection of the Constitutionality of the Laws) (1986) 2 Panstwo i Prawo 29-31.

78. Garlicki, idem, p.32. 
and the highest, central administrative organs-the Council of Ministers, ministers and the heads of other central departments.

Those officials and organs having the right to file an inquiry must consider the courts' notification, but their decision is completely within their discretion. Polish commentators argue that whatever the final decision will be, whether to file the inquiry or not, the Constitutional Tribunal must be informed of the regular court's decision. In this event, the Tribunal can, at least in theory, initiate a review itself. ${ }^{79}$

\section{E. Proceedings}

The proceedings before the Constitutional Tribunal have the characteristics of a trial. The officials or representatives of the organ which filed the petition or inquiry must be present. The organ which adopted the challenged normative act may be represented by the ProcuratorGeneral; however, the attendence of the Procurator is mandatory if the case is being heard by the plenum of the Court (which is a meeting of the entire court membership). The Tribunal examines witnesses, experts and evidence and then issues a written decision together with an opinion. The trial is public unless the case deals with security, defence or other matters which are top State secrets.

Panels of five justices hear petitions and inquiries which challenge the constitutionality of statutory acts. Cases dealing with sub-statutory acts are heard by panels of three judges. ${ }^{80}$ The plenum composed of seven judges and the president of the Court sits when a "particularly difficult" case is to be heard, ${ }^{81}$ such as impeachment of a judge of the Tribunal and petitions filed for reconsideration. ${ }^{82}$

Decisions of the Tribunal are final and not appealable. In the light of this provision, ${ }^{83}$ the possibility of reconsideration of an apparent "final" decision seems inconsistent with the statute. Article 27, sections 2 and 3, however, provides for this possibility with regard to sub-statutory normative acts which are declared unconstitutional by the Tribunal. The statute provides that proceedings can be reopened and the case heard by the plenum if the appropriate petition for reconsideration is filed by the Council of Ministers, First Minister, State Council or its president within one month from delivery of the Tribunal's original decision.

The decision of the Tribunal on unconstitutionality of a normative act

79. Idem, pp.34-37.

80. Art. 6 of the Seym Resolution of 31 July 1985, on the detailed proceedings before the Constitutional Tribunal.

81. 1985 Statute, Art.25, s.2.

82. Idem, Art.27, s.2.

83. Ibid. see Czeszejko-Sochaki, op. cit. supra n.18, at pp.158-159. 
will affect former judicial decisions taken on the basis of the changed or invalidated act. The civil proceedings in such case may be reopened by a proper petition if submitted within five years from the date the court's original decision acquired legal force; for arbitration proceedings the limitation period is three years. Decisions in criminal cases may be annulled within three years from the date they came into force, and decisions in administrative proceedings are recognised as invalid immediately upon a finding of unconstitutionality. The statute does not, however, provide for any direct legal action to recover compensation for damage caused by the application of invalidated normative acts. The provisions which provided for precisely defined civil claims were omitted from the statute. ${ }^{84}$

\section{F. The Role of the Constitutional Tribunal}

During its first year of operation the Tribunal heard six cases. In most of them, the government lost or backed out, thereby repealing the act before it was declared unconstitutional. The most influential and broadly discussed decision was where the court forced the government to repeal a huge State-ordered increase in housing fees that would have affected 100,000 apartment owners. ${ }^{85}$

In Poland legal experts' opinions of the Constitutional Tribunal are so far very positive, although some specialists cautiously admit that the Tribunal attempts to win credibility, and it is too early to assess its potential. The laws under scrutiny are not usually good or bad per se. This general truth is particularly applicable to the evaluation of the socialist legal institutions. It is unquestionable that laws in socialist countries cannot be properly assessed without careful examination of their practical application. As Cappelletti wrote:

one must not forget that even the concept of "constitution" is different in Western and Eastern thought. In Western Europe, the constitution is conceived as a body of more or less permanent rules and principles which express the fundamental norms of the State and establish a programme for their realisation. In Eastern Europe, the constitution is perceived as a superstructure over economy, reflecting socio-economic results to be achieved. It aims at describing, not prescribing, the actual phase of a socio-economic order in action. ${ }^{86}$

This is the perspective that the statute on the Constitutional Tribunal should be assessed from. In a "formal" sense, its provisions do not

84. Idem, pp.62-73 and 164 .

85. Washington Post, 8 Mar. 1987.

86. Cappelletti, op. cit. supra n.8, at p.8. 
depart from the basic concept of judicial review in continental Europe. Its "material" significance, however will be determined by political, economic and social circumstances, and without more convincing practical tests it is difficult to assess the Constitutional Tribunal at this stage.

With all the optimism which accompanied the establishment of the Tribunal and the first year of its work, one reservation should be borne in mind by the student of the socialist judicial review. Despite the image of a truly independent court which the Tribunal tried to build last year, it is a judicial organ which can be easily subject to political control. The Tribunal's power to review is limited to cases brought by officially recognised organs and institutions. Individuals and even regular courts do not have direct access to the Tribunal.

Polish experts raised the point that before the establishment of the Tribunal, the courts were not permitted to debate the constitutionality of statutes. Now, their discretion has been extended to that topic. To notify the organs in which the right of inquiry is vested about any conflicts between statutes and constitution, the courts must consider the question of constitutionality of statutes. It is true, however, that their suggestions may not be acted upon if the organs authorised to file an inquiry so decide. These organs are fully controlled by the party, thus the court's initiative can be blocked at any time by decisions of the leading party organs.

It is true that the Polish courts are now permitted to debate the constitutionality of a statute. But before the adoption of the statute establishing the Constitutional Tribunal, the judges were bound only by statutes and, as Polish experts argued, they could not question the constitutionality of the statutes but could challenge sub-statutory normative acts as not complying with the constitution or statutes. Theoretically it was permissible to challenge such acts, but this discretion was never exercised simply because there were no procedural regulations determining the practical steps a judge could take, neither could he foresee the possible consequences of his action. It is easy to see that, taking into. account the limited access to the Tribunal, its now impressive independence could easily be curbed by the political control of those organs having the right to initiate Tribunal proceedings.

On the other hand, it is often observed that the socialist system is in fact very conservative. Once established, institutions have a real chance of survival if they do not directly challenge the rudiments of the power of the communist elite. This is particularly true in Poland which for decades has tried to accommodate both the enormous social prestige of the Catholic Church and the political power of the communist party as well as accommodating extensive private land ownership with the socialist concept of collectivisation. There is no doubt that in socialist Poland the chances for survival of the institution of judicial review are relatively 
greater than in other countries within the Soviet bloc. With time the Polish experience of judicial review may contribute significantly to the liberalisation of the whole socialist legal system. This process warrants special consideration. 